Vienna Yearbook of Population Research 2007

Austrian Academy of Sciences, Vienna 


\section{Vienna Yearbook of Population Research 2007}

All articles in this publication, except those published in Demographic

Debates and Data \& Trends sections, were subject to international peer review

Internet address: www.oeaw.ac.at/vid/yearbook/

\section{Editorial board \\ Editor: \\ Wolfgang Lutz \\ Managing editor: \\ Tomáš Sobotka}

\section{Associate editors:}

Henriette Engelhardt-Wölfler, Thomas Fent, Richard Gisser, Dimiter

Philipov, Alexia Prskawetz, Sergei Scherbov

Vienna Institute of Demography

Austrian Academy of Sciences

Wohllebengasse 12-14

1040 Vienna, Austria

Fax: (+43 1) $51581-7730$

e-mail:vid@oeaw.ac.at

Website: www.oeaw.ac.at/vid

\section{Publisher}

Verlag der Österreichischen Akademie der Wissenschaften

Postfach 471, Postgasse 7

1011 Vienna, Austria

Tel. (+43 1) 515 81-3401-3406

Fax (+43 1) 515 81-400

e-mail:verlag@oeaw.ac.at Website:verlag.oeaw.ac.at

Cover design: Friedl Nussbaumer

Copy editing: Werner Richter and Sylvia Trnka

Layout: Ani Minassian, Barbara Maschat and Tomáš Sobotka

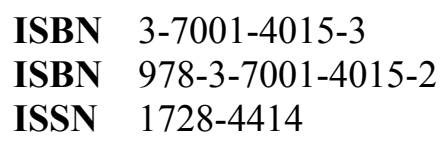

ISBN 3-7001-4015-3

ISBN 978-3-7001-4015-2

ISSN $\quad 1728-4414$ 


\section{Referees of papers submitted in 2003-2007}

The editors of Vienna Yearbook of Population Research would like to thank the following referees for reviewing papers submitted to this journal

Alicia Adsera
Maarten Alders
Marty Anderies
Gunnar Anderson
Evgueni Andreev
Francesco C. Billari
David E. Bloom
Riccardo Borgoni
Nikolai Botev
Thomas Burch
Christoph Bühler
Robert Clark
Sara R. Curran
David Coleman
Joop de Beer
Gianpiero Dalla Zuanna
Richard Disney
Gabriele Doblhammer-Reiter
Uwe Dulleck
Rudolf Winter-Ebmer
Josef Ehmer
Henriette Engelhardt
Heinz Fassmann
Thomas Fent
Ursula Ferdinand
Peter Findl
Jochen Fleischhacker
Anne H. Gauthier
Richard Gisser
Joshua R. Goldstein
Alexander Hanika

Karsten Hank

Frank Heiland

Maria M. Hofmarcher

Johannes Huinink

Miranda Jansen

Leiwen Jiang

Nico Keilman

Mirela Keuschnigg

Iliana Kohler

Peter M. Kort

Thomas Kögel

Michaela Kreyenfeld

Gerrit Kronjee

Michael Kuhn

Jean-Marie Le Goff

Markus Leibrecht

Harold Lentzner

Henri Leridon

Ron Lestaeghe

Aart C. Liefbroer

Wolfgang Lutz

Mark Luy

Landis MacKellar

Rainer Mackensen

Bo Malmberg

France Meslé

Raffaele Miniaci

Mark Montgomery

S. Philip Morgan

Norbert Neuwirth

Steve Ney 


\author{
Máire Ní Bhrolcháin \\ José Antonio Ortega Osona \\ Fred C. Pampel \\ Dimiter Philipov \\ Louis Pol \\ Alexia Prskawetz \\ Roland Rau \\ Robert D. Retherford \\ Sergio Rinaldi \\ Giulia Rivellini \\ German Rodriguez \\ Jan Rouwendal \\ Yasuhiko Saito \\ Sergei Scherbov \\ Vladimir Shkolnikov \\ Stefan Siedentop \\ Tomáš Sobotka
}

Marcelo Soto

Jeroen Spijker

Dietrich Stauffer

Cecilia Tomassini

Laurent Toulemon

Gerard J. van den Berg

Jeroen van Ginekken

Evert van Imhoff

Christine van Peer

David Voas

Andrea Weber

A. Weigl

Frans Willekens

Maria Winkler-Dworak

Franz Wirl

Guangyu Zhang

Uta Ziegler 


\section{Authors for this volume}

Carolina Berghammer, PhD-student, Vienna Institute of Demography, Austrian Academy of Sciences, Vienna, Austria

Isabella Buber, Vienna Institute of Demography, Austrian Academy of Sciences, Vienna, Austria

Gui Ying Cao, Forestry Program, International Institute for Applied Systems Analysis (IIASA), Laxenburg, Austria

David A. Coleman, Oxford Centre for Population Research, Oxford, United Kingdom

Paul Demeny, Population Council, New York, USA

Dalkhat Ediev, Vienna Institute of Demography, Austrian Academy of Sciences, Vienna, Austria

Gustav Feichtinger, Vienna Institute of Demography, Austrian Academy of Sciences, Vienna, Austria

Katrin Fliegenschnee, Vienna Institute of Demography, Austrian Academy of Sciences, Vienna, Austria

Inga Freund, Vienna Institute of Demography, Austrian Academy of Sciences, Vienna, Austria

Richard Gisser, Vienna Institute of Demography, Austrian Academy of Sciences, Vienna, Austria

Anne Goujon, Vienna Institute of Demography, Austrian Academy of Sciences, Vienna, Austria and International Institute for Applied Systems Analysis, Laxenburg, Austria

Jonathan Grant, RAND Europe, Cambridge United Kingdom

Dominik Grafenhofer, University of Toulouse, France

Stijn Hoorens, RAND Europe, Cambridge, United Kingdom

Diana Hummel, Institute for Social-Ecological Research, Frankfurt, Germany

Christian Jaag, University of St.Gallen and Swiss Post, Switzerland

Samir K.C., World Population Program, International Institute for Applied Systems Analysis (IIASA), Laxenburg, Austria

Christian Keuschnigg, University of St.Gallen, St.Gallen, Switzerland

Mirela Keuschnigg, University of St.Gallen, St.Gallen, Switzerland

Wolfgang Lutz, World Population Program, International Institute for Applied Systems Analysis, Laxenburg, Austria, and Vienna Institute of Demography, Austrian Academy of Sciences, Vienna, Austria 
Alexandra Lux, Institute for Social-Ecological Research (ISOE), Frankfurt, Germany

Dimiter Philipov, Vienna Institute of Demography, Austrian Academy of Sciences, Vienna, Austria

Alexia Prskawetz, Vienna Institute of Demography, Austrian Academy of Sciences, Vienna, Austria

Ren Qiang, Institute of Population Research, Peking University, Beijing, PR China

Fernando Riosmena, Institute of Behavioral Science and Department of Geography, University of Colorado at Boulder, USA

Warren Sanderson, Departments of Economics and History, State University of New York at Stony Brook, USA and World Population Program, International Institute for Applied Systems Analysis (IIASA), Laxenburg, Austria

Sergei Scherbov, Vienna Institute of Demography, Austrian Academy of Sciences, Vienna and World Population Program, International Institute for Applied Systems Analysis (IIASA), Laxenburg, Austria

Franz Schwarz, Vienna Institute of Demography, Austrian Academy of Sciences, Vienna, Austria

Vegard Skirbekk, International Institute for Applied Systems Analysis, Laxenburg, Austria

Jeroen Spijker, Centre d'Estudis Demogràfics, Universitat Autònoma de Barcelona, Barcelona, Spain

Pawel Strzelecki, Institute of Statistics and Demography, Warsaw School of Economics, Warsaw, Poland

Vladimír Špidla, Commissioner for Employment, Social Affairs and Equal Opportunities,European Commission, Brussels, Belgium

Maria Rita Testa, Vienna Institute of Demography, Austrian Academy of Sciences, Vienna, Austria

Frans Van Poppel, The Netherlands Interdisciplinary Demographic Institute, The Hague, the Netherlands

Leo Van Wissen, Faculty of Spatial Sciences, University of Groningen, the Netherlands and The Netherlands Interdisciplinary Demographic Institute, The Hague, the Netherlands

Maria Winkler-Dworak, Vienna Institute of Demography, Austrian Academy of Sciences, Vienna, Austria

Xiaoying Zheng, Institute of Population Research/WHO Collaborating Center on Reproductive Health and Population Science, Peking University, China Population Association, China 